\title{
HUBUNGAN ANTARA MOTIVASI BELAJAR DAN STATUS GIZI TERHADAP HASIL BELAJAR PENJASORKES DI SD NEGERI 40 SUNGAI LAREH KOTA PADANG.
}

\author{
Ali Umar ${ }^{1}$, Syamsuar Abbas $^{2}$, Syahrastani $^{3}$ \\ ${ }^{1}$ Program Studi Pendidikan Jasmani Kesehatan dan Rekreasi, Fakultas Ilmu Keolahragaan, \\ Universitas Negeri Padang. Jalan Prof. Dr. Hamka Air Tawar Barat, Padang, 25132, Indonesia. \\ ${ }^{2}$ Program Studi Ilmu Keolahragaan, Fakultas Ilmu Keolahragaan, Universitas Negeri Padang. Jalan \\ Prof. Dr. Hamka Air Tawar Barat, Padang, 25132, Indonesia. \\ ${ }^{3}$ Program Studi Ilmu Keolahragaan, Fakultas Ilmu Keolahragaan, Universitas Negeri Padang. Jalan \\ Prof. Dr. Hamka Air Tawar Barat, Padang, 25132, Indonesia. \\ E-mail: aliumar@ fik.unp.ac.id ${ }^{1}, \underline{\text { syamsuarabbas@ fik.unp.ac.id }}{ }^{2}, \underline{\text { syahrastani @ fik.unp.ac.id }^{3}}$
}

\begin{abstract}
ABSTRAK
Berdasarkan observasi yang dilakukan di lapangan terhadap siswa SD Negeri 40 Sungai Lareh Kota Padang bahwa dalam mengikuti mata pelajaran ditemukan kurangnya pencapaian terhadap hasil belajar ini terlihat dari hasil semester terdahulu bahwa nilai siswa masih di bawah ratarata atau di bawah standar kelulusan sehingga banyak siswa remedial, diduga faktor penyebabnya adalah motivasi belajar dan status gizi siswa. Tujuan penelitian ini adalah untuk mengetahui hubungan antara motivasi belajar dan status gizi terhadap hasil belajar siswa SD Negeri 40 Sungai Lareh Kota Padang.

Penelitian ini bersifat korelasional yaitu untuk mengetahui seberapa jauh suatu variabel berkaitan dengan variabel yang lainnya. Populasi dalam penelitian ini adalah seluruh siswa SD Negeri 40 Sungai Lareh Kota Padang yang berjumlah 148 orang. Pengambilan sampel dilakukan dengan teknik purposive Sampling yaitu siswa kelas V dan VI laki-laki saja yang berjumlah 20 orang. Data yang diperoleh dianalisis dengan rumus korelasi Product Moment sederhana dan Ganda.

Berdasarkan dari hasil penelitian ini terdapat hubungan yang signifikan antara motivasi belajar dengan hasil belajr penjasorkes, dimana $r_{\text {tab }}$ pada taraf signifikan $\alpha(0,05)=0,444$ berarti $r_{\text {hitung }}$ $(0,497)>r_{\text {tab }}(0,444)$. Kemudian juga terdapat hubungan yang signifikan antara status gizi terhadap hasil belajar penjasorkes, dimana $r_{\text {tab }}$ pada taraf signifikan $\alpha(0,05)=0,444$ berarti $r_{\text {hitung }}(0,485)>r_{\text {tab }}$ $(0,444)$. Selanjutnya terdapat hubungan yang signifikan secara bersama-sama antara motivasi belajar dan staus gizi terhadap hasil belajar penjasorkes di SD Negeri 40 Sungai Lareh Kota Padang, dimana $\mathrm{r}_{\text {tab }}$ pada taraf signifikan $\alpha(0,05)=0,444$ berarti $\mathrm{R}_{\text {hitung }}(0,609)>\mathrm{r}_{\text {tab }}(0,444)$.
\end{abstract}

Kata Kunci: Motivasi Belajar, Status Gizi, Hasil Belajar 


\section{PENDAHULUAN}

Pendidikan

adalah proses

komunikasi antara pendidik dan siswa yang merupakan media bagi pengembangan kualitas sumber daya manusia, yang dalam hal ini adalah peningkatan kualitas kesegaran jasmani, oleh karena itu peningkatan mutu pendidikan dasar perlu mendapat perhatian yang sungguh-sungguh terutama pada peserta didik yang berada di tingkat Sekolah Dasar. Hal tersebut dilakukan karena peserta didik yang berada di tingkat Sekolah Dasar merupakan pondasi bagi seluruh jenjang pendidikan.

Pendidikan jasmani yang diberikan merupakan bagian integral dari pendidikan secara keseluruhan. Bertitik tolak pada pernyataan Depdiknas (2003:1) bahwasanya:

"Pendidikan Jasmani bertujuan untuk mengembangan aspek kesehatan, kesegaran jasmani, keterampilan, berfikir kritis, kualitas emosional, keterampilan sosial, penalaran dan tindakan moral melalui kegiatan aktivitas jasmani olahraga. Tidak ada pendidikan yang tidak mempunyai sasaran pedagogis, dan tidak ada pendidikan yang lengkap tanpa adanya pendidikan jasmani, karena gerak sebagai aktivitas jasmani dasar bagi manusia untuk mengenal dunia dan dirinya sendiri yang secara alamiah berkembang searah dengan perkembangan zaman".

Berdasarkan kutipan di atas jelas bahwa pendidikan jasmani olahraga dan kesehatan yang di ajarkan disekolah memiliki peranan penting, yaitu memberi kesempatan kepada peserta didik untuk terlibat walaupun dalam berbagai pengalaman belajar, karena dengan adanya aktifitas jasmani yang di lakukan secara sistematis dapat mempengaruhi perubahan fisik yang lebih baik sehat jasmani dan rohani.

Secara umum tujuan dari belajar ada tiga jenis yaitu untuk mendapatkan pengetahuan (kognitif), penanaman konsep dan keterampilan (psikomotorik), dan pembentukan sikap (efektif). Tercapai tidaknya tujuan belajar di lihat dari aspek pengetahuan di tandai dengan kemampuan berpikir.

Dengan kata lain, tidak dapat mengembangkan kemampuan berpikir tanpa bahan pengetahuan, sebaliknya kemampuan berpikir akan memperkaya pengetahuan.Tercapai tidaknya tujuan belajar dilihat dari aspek pembentukan sikap akan terlihat dari sikap mental, prilaku, pengetahuan, dan keterampilan.

Setiap siswa pasti berkeinginan untuk mendapatkan hasil belajar yang baik. Keberhasilan siswa dalam belajar akan menjadi kebanggaan dalam diri siswa, orang tua, dan lingkungan sekitarnya. Salah satu indikator keberhasilan siswa dalam belajar adalah dengan mendapatkan hasil belajar yang sangat memuaskan atau mendapatkan nilai yang baik. Dengan demikian, tujuan belajar adalah ingin mendapatkan pengetahuan, keterampilan dan penanaman sikap mental.

Uraian di atas menjelaskan bahwa betapa pentingnya hasil belajar siswa yang baik, karena hasil belajar yang di peroleh mencakup segala aspek yang berkenaan dengan perubahan pengetahuan, penanaman konsep dan keterampilan, pembentukan sikap mental, prilaku dan pribadi anak didik kearah yang lebih baik yang diperoleh dari proses belajar.

Selain itu, berhasil tidaknya pencapaian tujuan pendidikan juga ditandai dengan hasil belajar yang dicapai siswa dari proses belajar di sekolah. Hasil belajar yang di capai siswa juga sangat di pengaruhi oleh sarana dan prasarana pendukung, kesegaran jasmani siswa, kemampuan guru dalam mengajar, lingkungan keluarga, dukungan kepala sekolah, motivasi belajar, dan status gizi.

Jadi apabila motivasi siswa, dan gizi siswa baik maka akan semakin baik hasil belajar yang di di peroleh siswa. Kesegaran jasmani seseorang baik maka hasil belajar siswa juga baik, karena akan menimbulkan motivasi untuk belajar. Dengan kesegaran jasmani baik cara pola 
pikir serta daya pikir siswa tersebut akan bagus untuk menerima pelajaran dari guru. Proses belajar seseorang akan terganggu apabila kesehatan dan kesegaran jasmani seseorang tersebut terganggu.

Dengan kata lain bahwa semakin baik tingkat kesegaran jasmani seseorang, maka semakin baik pula hasil belajar yang diperolehnya. Sebaliknya semakin rendah kesegaran jasmani seseorang, maka makin rendah pula hasil belajarnya". Dari uraian di atas dapat dikemukakan bahwa antara kesegaran jasmani dengan hasil belajar memiliki kaitan yang sangat erat, karena jika siswa memiliki kesegaran jasmani yang baik, maka akan dapat membantu siswa tersebut dalam menghadapi proses pembelajaran dengan penuh semangat tanpa merasa lesu dan ngantuk. Sebaliknya apabila kesegaran jasmani siswa rendah mereka merasa tidak konsentrasi dalam menghadapi pelajaran mudah ngantuk, lelah, letih, dan lesu yang mereka alami. Apabila ini terjadi maka siswa tersebut akan susah memahami dan menyerap materi yang diberikan guru, itu akan mengakibatkan rendahnya hasil belajar yang diperoleh siswa.

Motivasi belajar siswa juga berpengaruh terhadap hasil belajar karena motivasi merupakan kondisi psikologis yang mendorong seseorang untuk memenuhi kebutuhannya menikuti pelajaran. Motivasi dapat juga dikatakan serangkaian usaha untuk menyediakan kondisi-kondisi tertentu sehingga seseorang itu mau dan ingin mengikuti proses pembelajaran.

Sama dengan motivasi maupuan kesegaran jasmani, Status gizi juga sangat berpengaruh terhadap hasil belajar apabila gizi seseorang baik maka dia akan semangat dalam proses belajar mengajar tanpa rasa lelah, lesu, dan ngantuk saat proses belajar mengajar berlangsung. Karena status gizi merupakan sebagai zat pelindung dalam tubuh dengan menjaga keseimbangan cairan tubuh.

Yang harus di lakukan untuk menjaga status gizi seseorang adalah makanlah makanan bergizi seperti: karbohidrat, lemak, protein,vitamin, dan minum air yang cukup.Yang harus di perhatikan agar mendapat hasil belajar yang baik maka jagalah kesegaran jasmani dan status gizi dengan baik dengan cara melakukan kegiatan fisik, olahraga teratur, dan memakan makanan bergizi.

Masih banyak faktor-faktor pendukung untuk mendapatkan hasil belajar yang selain dari motivasi, kesegaran jasmani maupun status gizi yaitu sarana dan prasarana. Sarana dan prasarana termasuk penunjang mendapatkan hasil belajar yang baik, jika sarana dan prasarana memadai akan memudahkan siswa untuk berlatih maupun bermaian untuk mendapatkan hasil belajar yang maksimal.

Uraian di atas menjelaskan bahwa sekian banyak faktor yang mendukung untuk mendapatkan hasil belajar diduga motivasi, dan status gizi sangat berperan penting. Jika siswa memiliki motivasi dan status gizi yang baik maka siswa akan dapat mengikuti proses belajar mengajar dengan semangat, kosentrasi, dan akan mudah menyerap materi yang di berikan guru dan yang pasti akan mendapatkan hasil belajar yang baik. Selain itu faktor pendukung lain seperti kesegaran jasmani, sarana dan prasarana maupun fakror yang lain.

Kenyataan yang di temukan dari informasi yang diterima dari guru di SDN 40 Sungai lareh Kota Padang menyatakan bahwa, kualitas hasil belajar masih rendah. Ini terbukti dari hasil nilai ujian semester 1 masih di bawa rata-rata atau di bawah standar kelulusan sehingga banyak siswa melakukan remedial pada mata pelajaran yang gagal tersebut, dengan demikian siswa harus mengikuti ujian kembali. Hal ini disebabkan motivasi siswa, dan status gizi siswa yang mengakibatkan fisik anak lemah dan ketidak seimbangan tubuh.

Selama kegiatan observasi yang di lakukan di SDN 40 Sungai Lareh Kota Padang memang benar ada beberapa orang 
siswa hasil belajarnya rendah ini diduga salah satu penyebabnya adalah kurangnya motivasi siswa dalam mengikuti proses belajar mengajar, dan status gizi siswa sehingga tidak semangat dalam mengikuti proses belajar mengajar.

Pembelajaran pada hakekatnya adalah interaksi antara siswa dengan lingkungannya sehingga terjadi perubahan kearah yang lebih baik. Tugas guru yang paling utama adalah mengkondisikan lingkungan agar menunjang terjadinya perubahan perilaku bagi siswa, perilaku guru dalam membelajarkan siswa merupakan salah satu factor keefektifan kegiatan pembelajaran, dengan melaksanakan pengajaran yang berawal dari perencanaan sampai evaluasi sehingga tujuan yang hendak dicapai berlangsung dengan baik.

Perilaku pembelajaran yang diterapkan guru dalam proses pembelajaran yang dimaksudkan untuk dapat melaksanakan komponen-komponen pembelajaran, guru yang baik adalah guru yang menguasai bahan ajar, mengorganisasikan, menyajikan bahan secara jelas, mempunyai penampilan yang baik, menggunakan teknik motivasi yang bervariasi, membaca dan memeriksa tugas-tugas siswa dan memelihara disiplin yang dilakukan untuk pencapaian tujuan pembelajaran.

Karakteristik guru yang efektif adalah mempunyai anggapan yang kuat bahwa siswa akan berhasil dalam belajar, memaksimalkan kesempatan siswa untuk terlibat dalam pengalaman belajar, mengatur waktu dan mengolah kelas secara efisien, dan menyusun bahan pelajaran.

Dalam pelaksanaan pembelajaran semuanya tergantung pada tujuan pembelajaran apa yang akan diberikan, kemudian siswa mengembangkan gerakan yang telah guru berikan dengan kata lain pembelajaran dipusatkan pada siswa agar aktif dalam mengikuti pembelajaran. Tujuan akhir pembelajaran pendidikan jasmani adalah hasil gerakan atau keterampilan yang dapat dilakukan oleh siswa melalui proses yang telah ditentukan. Psikomotor merupakan tujuan utama namun tidak berarti aspek-aspek pendidikan yang lain diabaikan seperti aspek kognitif dan afektif.

Sebaliknya aspek-aspek yang lain juga dilihat dalam pelaksanaan pembelajaran, bagaimana siswa bekerja sama dan mampu menerima pelajaran yang diberikan guru, guru sangat berperan penting dalam keberhasilan siswa mengikuti pembelajaran yang disajikan. Melalui metode-metode yang diterapkan dan dibutuhkan serta keterampilan guru untuk memberikan penjelasan yang baik secara verbal maupun non verbal dan jika memungkinkan guru juga dapat menggunakan media gambar atau media elektonik untuk memudahkan siswa dalam pembelajaran adalah metode deduktif atau dengan metode perintah dan tugas, yaitu dengan demontrasi, menjelaskan gerakan dan sebagainya. Sehingga siswa mampu menerapkan dalam pelaksanaan pembelajaran sehingga tujuan yang diharapkan dapat tercapai.

\section{Hasil Belajar Penjasorkes}

Hasil belajar merupakan dasar untuk menentukan tingkat keberhasilan siswa dalam memahami suatu meteri pelajaran. Menurut Jufri dalam Karim (2000:20) "hasil belajar adalah perubahan yang terjadi dalam diri siswa atau anak didik sebagai bukti bahwa ia telah melakukan proses belajar mengajar". Bila seseorang telah melakukan proses belajar maka dalam dirinya akan mengalami perubahan-perubahan yang merupakan akibat dari proses belajar.

Menurut W.s wingkels (1987:27) menyatakan "Belajar merupakan proses psikis yang berlangsung dalam interaksi aktif subjek dengan lingkungan dan menghasilkan perubahan-perubahah dalam pengetahuan, pemahaman, keterampilan, nilai, sikap yang bersifat konsisten atau tetap". 
Proses pembelajaran suatu aktivitas yang berlangsung dengan melibatkan banyak komponen yang saling berinteraksi. Belajar merupakan suatu proses yang ditandai dengan adanya perubahan diri seseorang.

Sebagaimana yang dikemukakan oleh Hakim (1992:1) "Bahwa belajar adalah suatu proses perubahan didalam kepribadian manusia dan perubahanperubahan itu ditampilkan dalam peningkatan kualitas dan kuantitas tingkahlaku seperti peningkatan kecepatan, pengetahuan , sikap, kebiasaan, pemahaman, keterampilan, daya fikir dan lain-lain".

Jika kita bertanya kepada seseorang tentang apakah belajar, kita akan memperoleh berbagai jawaban. Hal ini sesuai dengan yang diungkapkan oleh Soemanto (1990:98) "Bahwa banyak orang yang berangapan bahwa yang dimaksud dengan belajar adalah mencari ilmu pengetahuan". Sebagaimana yang telah dikemukan tersebut bahwa dalam pencarian ilmu pengetahuan ini akan menghasilkan perubahan-perubahan sikap yang mengarah kearah yang lebih baik dalam individu tersebut.

Belajar berhubungan dengan perubanhan tingkahlaku seseorang yang terjadi pada diri individu, sesuai dengan pendapat Dalyono (2005:49) menjelaskan bahwa "Belajar adalah suatu usaha perubahan yang dilakukan secara sungguh-sungguh dengan sistematis mendayaguanakan semua potensi yabg dimiliki, baik fisik, mental, serta dana, panca indra, otot dan lainya, sedemikian pula aspek-aspek kejiwaan seperti inteligensi, bakat, motivasi, minat dan sebagainya".

Menurut Hilgerd, Dkk dan Dalyono (2005:211) bahwa: "Belajar berhubungan dengan perubahan tingkahlaku seseorang terhadap sesuatu situasi tertentu yang sisebabkan oleh pengalamanya yang berulang-ulang dalam situasi itu, dimana perubahan tingkahlaku tidak dapat dijelaskan atas dasar kecendrungan, kematangan atau keadaan sesaat seseorang (kelelahan, pengaruh obat dan sebagainya)".

Menurut Sukmadinata (2003:179) "Hasil belajar merupakan realisasi atau pemahaman dari kacakapan-kecapan potensial atau kapasitas yang dimiliki seseorang. Penguasaan hasil belajar seseorang dapat dilihat dari tingkahlaku baik prilaku dalam bentuk penguasaan pengetahuan, keterampilan berfikir maupun keterampilan motorik".

Belajar merupakan proses dan perkembangan hidup manusia, dengan belajar manusia melakukan perubahan kualitatif sehingga tingkahlakunya berkembang. Semua aktivitas dan prestasi manusia tidak lain adalah hasil belajar.

Orang bekerja berdasarkan atas dasar apa yang telah dipelajarinya. Belajar itu bukan hanya hasil. Ahmadi (1991:121) Menyatakan pendapatnya bahwa perubahan sebagai hasil belajar " Belajar dalam arti luas dapat diartikan sesuatu proses usaha yang dilakukan individu untuk memperoleh suatu perubahan tingkah laku yang baru secara keseluruhan pengalaman individu itu sendiri dalam interaksi dengan lingkungan".

Jadi dari sekian banyak definisi para ahli dapat di ambil kesimpulan belajar adalah usaha untuk perubahan tingkah laku seseorang dari sebelum nya tidak tahu menjadi tahu dari sebelumya tidak bisa menjadi bisa dari pengalaman dan interaksi dengan lingkungannya.

Prestasi belajar adalah istilah yang diguanakan untuk menunjukan pada suatu pencapaian keberhasilan terhadap suatu tujuan, karena usaha yang telah dilakukan seseorng. Prestasi menunjukan kepada tingkat keberhasilan yang telah dicapai dari hasil evaluasi selama mengikuti pendidikan. Dalam belajar prestasi menujukan kepada tingkat keberhasilan oleh siswa dalam usaha yang diselenggarakan oleh penyelenggara terutama guru. 


\section{a. Faktor-faktor yang Mempengaruhi Hasil Belajar penjasorkes}

Menurut Depdikbud (1993:5) Hasil

belajar siswa dipenggaruhi oleh dua faktor yaitu faktor internal dan faktor eksternal siswa itu sendiri :

“1) Faktor Internal (berasal dari dalam diri siswa) (a) Kecerdasan, keceradasn sangat pentingsekalin untuk menentukan keberhasilan studi siswa, anak yang cerdas memungkin sekali prestasi belajarnya baik ; (b) Bakat, bakat adalh kemampuan yang dharus dikembangkan melalui proises belajar, setiap siswa mempunyai nbakat yang berbeda-beda ; (c) Minat dan perhatian, Apabila siswa berminat pada suatu mata pelajaran maka siswa tersebut cendrung untuk memperhatikan dan memehami secara mendalam.

2) Faktor Eksternal (faktor yang berasal dari luar diri siswa) (a) Lingkungan yang tediri dari lingkungan alam, lingkungan keluarga, dan lingkungan masyarakat. Keadaan lingkungan sangt be[pengaruh terhadap prestasi belajar seperti cuaca, keadaan lingkungan keluarga juga sangat mendukung belajar, anak-anak yang mendapatkan dukungan dari keluaraga yang damai akan meningkatkan prestasi belajarnya, serta lingkungan masyarakat yang mendukung prestasi belajar seperit pergaulan yang mendukung ; (b) peralatan belajar, dalam kegiatan belajar untuk mencapai prestasi yang baik perlinya sarana prasarana yang mendukung".

Semua faktor yang mempengaruhi hasil belajar baik faktor internal maupun faktor eksternal sangat berpengaruh terhadap hasil belajar sehingga membuat siswa tidak dapat mencapai hasil belajar apabila masih dipenggaruhi faktor-faktor diatas. Salah satu faktor yang terpenting mempengaruhi hasil belajar siswa adalah tingkat kesegaran jasmani siswa tersebut, karena hal ini langsung berkaitan dengan siswa dalam proses belajar mengajar.

\section{b. Penilaian Hasil Belajar}

Penilai hasil belajar memiliki tujuan tersendiri dalam pembelajaran, Arikunto (1992:7) mengemukakan bahwa : "tujuan penilaian hasil belajar adalah untuk mengetahui siswa mana yang berhak melanjutkan pelajaran karena telah berhasil menguasai materi ataukah materi pelajaran telah tepat atau belum".

Dalam penelitian ini hasil belajar yang dimaksud adalah suatu yang diperoleh siswa melalui proses belajar mengajar yang mencerminkan penguasaan materi pelajaran oleh siswa, yang tergambar dalam bentuk skor nilai.

Menurut Arikunto (1992:22) mengemukakan bahwa : "Hasil belajar adalah kemampuan-kemampuan yang dimiliki siswa setelah mengalami proses pembelajaran.

Hasil belajar seorang peserta didik biasanya dinyatakan dengan angka, untuk mendapatkan nilai tersebut biasanya dilakukan penilaian. Penilaian adalah upaya atau tindakan untuk mengetahui sejauh mana tujuan yang telah diterapkan itu tercapai, dengan kata lain tujuan itu adalah sebagai alat untuk mengetahui keberhasilan proses pembelajaran yang terjadi antara pendidik dan peserta didik. Penilaian kegiatan belajar dan niali hasil dapat dilakukan dengan suatu alat evaluasi yang berupa tes".

Jadi untuk mengetahui sejauh mana keberhasilan dalam proses belajar mengajar adalah dengan cara melalui tes dan dalam tes tersebut akan dapat melihat kemampuan peserta didik dalam memahami materi pelajaran dan guru akan bisa memberikan nilai yang pantas dan yang semestinya kepada peserta didik tersebut.

merupakan suatu energi penggerak, pengarah dan memperkuat tingkah laku.Witherington (1986:37) menegaskan pula bahwa : "motivasi merupakan struktur dari berbagai motif- 
motif atau faktor penggerak yang menyebabkan timbulnya prilaku tertentu pada diri seseorang".

Sarwono (1983:57) mengartikan motivasi sebagai : "keseluruhan proses perbuatan atau tingkah laku manusia, termasuk situasi yang mendorong, dorongan yang timbul dalam diri individu, tingkah laku yang ditimbulkan oleh situasi dan tujuan atau akhir dperbuatan tersebut".

Selanjutnya Whitaker seperti yang dikutip oleh Soemanto (1990:193) memberikan pengertian motivasi sebagai "kondisi-kondisi atau keadaan yang mengaktifkan atau memberi dorongan kepada makhluk untuk bertingkah laku mencapai tujuan yang ditimbulkan oleh motivasi tersebut".

Kemudian Winkell (1984:7) menyatakan bahwa motivasi merupakan : "Daya Penggerak dari dalam dan di dalam subjek untuk melakukan aktivitas-aktivitas tertentu demi mencapai suatu tujaun yang telah menjadi aktif".

Dengan memperhatikan beberapa pendapat yang berkenaan dengan definisi motivasi, maka dapat disimpulkan bahwa motivasi merupakan dorongan dan rangsangan yang terjadi di dalam diri individu yang diwujudkan kepada tingkah laku untuk memenuhi kebutuhan yang diinginkan. Dengan terwujudnya motivasi ke dalam bentuk tingkah laku, maka dapat diketahui dan diramalkan apa yang menjadi tujuan individu.

Ditinjau dari tipe dan penyebab terjadinya motivasi belajar Woodworth dan Marquis seperti yang dikuti Yusuf (1989:79), Winkell (1984:28), dan Prayitno (1989:10), dapat dikenal atas dua tipe motivasi yaitu motivasi instrinsik dan motivasi ekstrinsik.

Motivasi instrinsik merupakan "motif-motif yang berfungsi bukan diakibatkan pengaruh rangsangan dari luar" (Suryabrata, 1984:28), sedangkan Purwanto (1990:65) disebut motivasi instrinsik "Jika yang mendorong individu untuk bertindak adalah nilai-nilai yang terkandung di dalam objek itu sendiri”.
Sedangkan Winkel (1984:28) mendefenisikan : "sebagai bentuk motivasi yang di dalamnya aktivitas belajar dimulai dan diteruskan berdasarkan suatu dorongan yang secara mutlak berkaitan dengan motivasi belajar".

Seorang individu dalam memperlihatkan tingkah lakunya tidak hanya dipengaruhi oleh faktor lingkungan. Tapi karena adanya energi yang bersal dari dalam diri individu itu sendiri. Kegiatankegiatan yang ditunjukkan oleh tingkah lakunya merupakan kehendaknya sendiri untuk mencapai tujuan yang diinginkan.

Dengan memperhatikan beberapa pendapat teresebut di atas, maka dapatlah disimpulkan bahwa indicator motivasi intrinstik adalah: sikap, perasaan, minat, bakat, kebutuhan.

Dengan adanya motivasi ekstrinsik akan menggerakan dan mendorong peserta didik dalam mencari tujuan yang telah ditetapkan. Semakin tinggi makna yang hendak dicapai, akan berpengaruh terhadap kuatnya tingkat motivasi yang akan ditimbulkan.

Seorang pendidik dalam usaha membangunkan tingkat motivasi peserta didiknya secara efektif, yang dilakukan adalah dengan mempelajari kebutuhannya secara individual sehingga dapat menggunakan strategi pengajaran yang sesuai dengan kebutuhan peserta didiknya. Dengan demikian seorang pendidik dapat mempergunakan suatu strategi pengajaran yang sesuai dengan peserta didiknya.

Peserta didik yang termotivasi secara instrinsik pada hekekatnya memandang proses belajar mengajar hanyalah sebagai sarana atau alat dalam mencapai tujuannya. Sehingga tingkah laku yang biasanya diperlihatkan menganggap belajar bukan hal yang mutlak dapat mempengaruhi tujuan yang diigin dicapainya (Winkel, 1984:28).

Bertitik tolak dari pendapat ahli tersebut ternyata banyak memiliki kesamaan. Karena itu penulis simpulkan indicator motivasi ekstrinsik adalah teridi atas pujian, pemberitahuan kemajuan 
belajar, hadiah, hukuman, penghargaan dan persaingan.

\section{Motivasi Belajar}

Menurut Prayitno (1989:8) motivasi belajar tidak saja merupakan suatu energi yang menggerak siswa untuk belajar, tetapi juga sebagai usaha yang mengarahkan aktivitas siswa kepada tujuan belajar.

Suatu kenyataan yang perlu disadari oleh guru-guru bahwa siswa yang dihadapi dikelas tidak sama dengan yang lainnya. Siswa mempunyai perbedaan dalam banyak hal seperti berbeda kemampuan berfikir baik bakat dan minat, siswa yang lambat dalam belajar ssering mengalami kesulitan, sebab setiap akhir kegiatan belajar siswa belum mampu untuk menguasai seluruh materi, akan tetapi guru telah melanjutkan pada materi lainnya. Akibatnya timbul pada siswa tersebut lebih sering tidak ada perhatian dan minat terhaadap pelajaran, sehingga siswa tersebut sering membolos, datang terlambat, tidak mengerjakan PR, lambat dalam pelaksanaan tugas yang diberikan oleh guru.

Dari uraian di atas dapat diambil kesimpulam bahwa motivasi belajar adalah dorongan atau kekuatan dalam diri siswa yang menimbulkan kegiatan serta arah belajar untuk mencapai tujuan yang diinginkan.

\section{Status gizi}

Khumadi, (1994:5) menjelaskan bahwa: zat gizi adalah zat-zat yang di peroleh dari bahan-bahan makanan yang kita makan. Tiap-tiap makanan yang kita makan mempunyai nilai yang sangat penting bagi tubuh. Sedangkan menurut Sunita (2001:3) zat gizi merupakan "ikatan-ikatan kimia yang di perlukan tubuh untuk melakukan fungsinya, yaitu: menghasilkan energi, membangun dan memelihara jaringan serta mengatur proses kehidupan".

Berdasarkan kutipan di atas, dapat di simpulkan bahwa status gizi dapat di artikan sebagai ikatan-ikatan kimia yang di perlukan tubuh atau zat makanan yang di kosumsi seseorang merupakan indikator dari status gizi mereka. Energi yang di perlukan untuk kinerja fisik di peroleh dari metabolisme bahan makanan yang di kosumsi sehari-hari, sehingga makanan atau zat gizi merupakan salah satu penentu kuslitas kinerja fisik dan pertumbuhan serta perkembangan fisik seseorang.

Khumadi (1994:5) mengemukakan fungsi umum gizi yang di perlukan oleh seseorang mempunyai beberapa fungsi, yaitu: Untuk memelihara proes tubuh dalam pertumbuhan dan perkembangan terutama bagi mereka yang masih dalam proses pertumbuhan dan juga untuk memperoleh energy guna untuk melakukan kegiatan fisik sehari-hari

Kedua fungsi di atas, sudah termasuk memelihara proses tubuh dalam pertumbuhan perkembangan, di antaranya penggantian sel-sel yang rusak sebagai zat pelindung dalam tubuh dengan menjaga keseimbangan cairan tubuh. Apabila dalam mekanisme kerja organ tubuh terpenuhi dengan baik, maka akan berpengaruh positif terhadap kemampuan dan kesehatan tubuh, seperti memiliki daya pikir dan melakukan kegiatan fisik sehari-hari cukup tinggi.

Soetjiningsih

mengemukakan bahwa "Gizi yang tidak seimbang dapat mengganggu pertumbuhan seseorang sehingga terlihat anak kurang bersemangat, kurang bergairah, pucat, kurang darah, daya ingat menurun, lebih mudah di serang bibit penyakit dan mengantuk pada jam pelajaran. Sedangkan gizi lebih adalah gizi yang tidak seimbang yang dapat menyebabkan kelebihan berat badan atau obesitas"

Menurut Syafrizar (2009:4) status gizi adalah "keadaan tubuh sebagai akibat kosumsi, penyerapan dan penggunaan pangan di dalam tubuh". Sementara Khumadi (1994:6) mengemukakan bahwa: "Status Gizi adalah keadaan seseorang yang di akibatkan oleh konsumsi, penyerapan dan penggunaan zat-zat gizi 
dari makanan dalam jangka waktu yang lama.

Bobot (berat) adalah salah satu parameter penting dalam menentukan status kesehatan manusia, khususnya yang berhubungan dengan status gizi. Untuk semua kelompok umur, jenis kelamin, keadaan gizi sehat terletak pada selang angka yang menggambarkan tiga macam penampilan fisik, yaitu: gemuk, ideal, dan kurus.

Apabila lebih tinggi dari batas gemuk tidak termasuk dalam status gizi sehat dan di golongkan sebagai status gizi lebih (Obositas). Lebih rendah dari batas angka kurus juga tidak termasuk status gizi sehat dan di golongkan sebagai keadaan gizi kurang".

Dari kutipan diatas, jelaslah bahwa status gizi adalah keadaan seseorang yang di akibatkan oleh kosumsi, penyerapan dan mengkosumsi zat-zat makanan dalam waktu yang lama. Parameter penting dalam menentukan status gizi ini adalah bobot atau berat badan yang di miliki seseorang. Minsalnya saja seseorang yang memiliki badan dengan bobot yang lebih atau tidak seimbang dengan tinggi badannya, dia dapat di katakan sebagai orang tidak sehat status gizinya.

Menurut Riyadi (1995:13), "tinggi badan merupakan data atropometri yang mengambarkan keadaan pertumbuhan skeletal". Dalam keadaan normal, tinggi badan tumbuh bersamaan dengan pertumbuhan umur. Pertumbuhan tinggi badan tidak seperti beret badan, relative tidak sensitive terhadap masalah defesiensi gizi terhadap tinggi badan akan terlihat dalam waktu yang cukup lama,berat badan memiliki hubungan yang linier dengan tinggi badan. Dalam keadaan normal, perkembangan berat badan akan searah dengan pertumbuhan tinggi badan dengan kecepatan tertentu.

Untuk mendapatkn energy yang cukup atau gizi yang seimbang, maka berbagai kualitas berbagai unsur gizi yang terdapat dalam makanan juga harus seimbang atau cukup. Kekurangan atau kelebihan unsur gizi akan menyebabkan berbagai gangguan kesehatan tubuh,

Berdasarkan kutipan di atas dapat di artikan bahwa karbohidrat, protein dan lemak sangat penting bagi kesehatan tubuh. Tanpa karbohidrat yang cukup, orang akan lapar, lesu dan malas. Tanpa protein yang cukup akan menghambat perkembangan otak dan otot. Jika protein berlebihan dapat mendatangkan penyakit hati, kerja ginjal makin berat, dan penurunan kalsium tulang. Otot-otot yang berkembang dengan baik akan mempunyai kekuatan untuk melakukan berbagai aktifitas.

Tanpa kalsium tulang yang cukup maka pertumbuhan dalam tulang tidak akan berlangsung dengan baik. Tulang atau rangka tubuh kita juga sangat penting untuk menghasilkan kekuatan tubuh dengan baik.

Begitu juga kalau cadangan lemak dalam tubuh kita berlebihan, akan menyebabkan kegemukan yang dapat menyebabkan penyakit jantung, ginjal, diabetes,tekanan darah tinggi, gangguan pencernaan, dan penyakit degenerative lainnya.

Di samping karbohidrat, protein dan lemak yang cukup atau seimbang, tubuh kita juga membutuhkan vitamin, minsalnya: Vitamin A berfungsi untuk membantu penglihatan, membantu pertumbuhan, memelihara kulit, memelihara sistim reparasi, dan melindungi tubuh dari infeksi.

Vitamin B1 berfungsi untuk menjaga kesehatan selaput lendir, memelihara sistim syaraf, otot dan jantung. Vitamin D berfungsi untuk pertumbuhan, dan pemeliharaan tulang dengan penyerapan kalsium fosfor dari usus kecil, membantu pembentukan tulang dan gigi yang kuat, mempertahankan kesehatan darah, otot dan urat saraf.

Kekurangan atau kelebihan vitamin dapat menyebabkan gangguan kesehatan tubuh, minsalnya kekurangan vitamin A dapat menganggu kesehatan mata, seperti 
yang di kemukakan oleh Wirakusuma (1997:83-93) yaitu:

1) Kekurangan vitamin $A$ akan mengakibatkan kornea dan konjungtifa menjadi kering dan dapat menyebabkan keracunan.

2) Kekurangan vitamin B1 menyebabkan penyakit biri-biri, kehilangan nafsu makan, kerusakan sistim saraf, kelemahan otot, gangguan fungsi jantung dan sistim penapasan, kerusakan pencernaan.

3) Kekurangan vitamin $D$ dapat menyebabkan kerapuhan gigi dan tulang, serta beberapa penyakit kulit.

Dengan demikian dapat di pahami bahwa vitamin merupakan bagian dari unsur gizi yang harus dalam kondisi yang cukup sehingga dapat berfungsi dengan baik. Status gizi yang berlebihan dapat pula menyebabkan seseorang terlalu kegemukan, dan sebaliknya bila status gizi terlalu rendah dapat pula menyebabkan orang terlalu kurus.

\section{METODE}

Jenis penelitian ini adalah bersifat korelasional yang bertujuan untuk melihat hubungan antara variabel-variabel yaitu: variabel bebas adalah motivasi $\left(\mathrm{X}_{1}\right)$ dan status gizi $\left(\mathrm{X}_{2}\right)$, dan variabel terikat yaitu hasil belajar (Y) siswa SDN 40 Sungai Lareh Kota Padang. Penelitian ini di lakukan di SDN 40 Sungai Lareh Kota Padang, Sedangkan waktu penelitian di lakukan pada bulan November-Desember 2010.

Populasi dalam penelitian ini adalah siswa-siswi SDN 40 Sungai Lareh Kota Padang yang terdiri dari kelas I sampai kelas VI dengan jumlah 125 orang. Jadi seluruh siswa-siswi yang menjadi populasi adalah 125 orang. Untuk lebih jelasnya dapat kita lihat pada tabel 1 berikut ini:

Tabel 1. Populasi Penelitian

\begin{tabular}{|c|c|c|c|c|}
\hline \multirow{2}{*}{ No } & \multirow{2}{*}{ Kelas } & \multicolumn{2}{|c|}{ Jumlah siswa } & \\
\cline { 3 - 4 } & Putera & Puteri & Jumlah \\
\hline 2 & IV & 11 & 14 & 25 \\
\hline & V & 9 & 15 & 24 \\
\hline & Jumlah & 20 & 29 & 49 \\
\hline
\end{tabular}

Sumber: Tata usaha SDN 40 Sungai Lareh Kota Padang

Sampel adalah bagian dari populasi yang menjadi sumber data dan data yang sebenarnya dalam suatu penelitian dengan kata lain sampel adalah sebagian yang mewakili seluruh populasi.

Sampel dalam penelitian ini diambil dengan menggunakan teknik purposive sampling yaitu "pengambilan sampel didasarkan pada maksud yang telah ditetapkan sebelumnya atau dengan pertimbangan-pertimbangan

Dengan demikian Peneliti mengambil siswa kelas IV-V dengan alasan karena siswa kelas VI mereka dalam tahap persiapan mengikuti ujian akhir nasional (UN), sedangkan siswa kelas I-III peneliti merasa mereka masih belum cocok dilakukan tes. Jadi sampel pada penelitian ini hanya berjumlah 20 orang yaitu putera saja. Untuk lebih jelasnya dapat dilihat tabel berikut:

\section{Tabel 2. Sampel Penelitian}

\begin{tabular}{|c|c|c|}
\hline No & Kelas & $\begin{array}{c}\text { Jumlah } \\
\text { siswa } \\
\text { Putera }\end{array}$ \\
\hline 1 & IV & 11 \\
\hline 2 & V & 9 \\
\hline & Jumlah & 20 \\
\hline
\end{tabular}

Sumber: Tata usaha SDN 40 Sungai Lareh Kota Padang

Sesuai dengan tujuan yang ingin di capai maka jenis data dalam penelitian ini adalah data primer dan data skunder. Data primer adalah data yang di ambil langsung dari sampel penelitian yaitu pengukuran motivasi dan pengukuran status gizi, sedangkan data skunder adalah hasil belajar siswa yang di peroleh dari nilai rapor siswa.

Sumber data dalam penelitian ini adalah siswa-siswi SDN 40 Sungai Lareh Kota Padang yang meliputi kelas I sampai kelas VI yang di peroleh dari pihak sekolah dan yang terpilih sebagai sampel. 


\section{Teknik dan Alat Pengumpulan Data 1. Motivasi Belajar}

Instrumen yang digunakan untuk mengumpulkan data variabel motivasi belajar siswa (X1) penelitian ini adalah dengan menggunakan angket skala Likert dengan 5 (lima) alternatif jawaban, yaitu: Selalu (SL), Sering (SR), Kadang-kadang (KDG), Jarang (JR) dan Tidak Pernah (TP).

Sesuai dengan model kuesioner, maka untuk butir pernyataan positif diberi skor untuk jawaban $\mathrm{SL}=5, \mathrm{SR}=4, \mathrm{JR}=2$, dan $\mathrm{TP}=1$. Kemudian untuk pernyataan negatif diberi skor untuk jawaban $\mathrm{SL}=1$, $\mathrm{SR}=2, \mathrm{KD}=3, \mathrm{JR}=4$ dan $\mathrm{TP}=5$. Adapun langkah-langkah dalam penyusunan angket sebagai berikut:

a. Menganalisis variabel menjadi indikator.

b. Membuat kisi-kisi instrumen berdasarkan indikator yang ditetapkan.

c. Menyusun butir angket berdasarkan indikator yang telah ditetapkan.

d. Mengkonsultasikan angket tersebut dengan pembimbing.

e. Melakukan uji coba instrumen, untuk mengetahui validitas dan reliabilitas angket yang akan digunakan terhadap 10 orang siswa dalam kelompok populasi yang sama diluar sampel yang digunakan.

\section{Status Gizi}

Intrumen yang di gunakan untuk mengukur gizi siswa adalah pengukuran status gizi anak dengan NHCS. Kemudian status gizi anak di kelompokan dalam empat kategori yaitu:

Tabel 3. Status Gizi Berdasarkan

Indeks Antropometri \% Median

\begin{tabular}{|ll|c|}
\hline \multicolumn{2}{|c|}{ STATUS GIZI } & Indeks BB/TB \\
\hline Gizi Baik & (GB) & $>90 \%$ \\
\hline Gizi Sedang & (GS) & $81 \%-90 \%$ \\
\hline Gizi Kurang & (GK) & $71 \%-80 \%$ \\
\hline $\begin{array}{l}\text { Gizi } \\
\text { (GBK) }\end{array}$ & Buruk & $\leq 70 \%$ \\
\hline
\end{tabular}

Sumber : Supariasa, (2001: 70)

Cara-cara yang di lakukan dalam pengumpulan data yang berhubungan dengan status gizi yaitu: a. Menimbang berat badan siswa dengan timbangan orang dalam bentuk satuan berat $\mathrm{kg}$. Mengukur tinggi badan sampel dalam bentuk satuan panjang yaitu meter.

b. Menghitung Indeks Berar Badan Menurut (BB/U) sampel

c. Melihat klasifikasi gizi anak dengan pedoman buku NCHS.

d. alat yang di gunakan untuk mengukur kadar gizi siswa yaitu:

1) Timbangan orang dalam satuan $\mathrm{kg}$

2) Pendataan secara sekunder yang meliputi nama murid, umur, jenis kelamin,dan pekerjaan orang tua.

3) Pengukuran berat badan ada murid, dengan alat ukur timbangan dan di catat pada formulir penimbangan.

4) Anak di panggil satu persatu berdasarkan absensi anak

5) Anak sewaktu di timbang harus buka sepatu dan mengeluarkan barang dari sakunya sebelum menaiki timbangan

6) Ketika diatas timbangan, maka di lihat berapa berat siswa tersebut.

\section{Hasil belajar}

Untuk mendapatkan data tentang hasil belajar siswa kelas IV sampai kelas $\mathrm{V}$ yaitu hasil belajar penjasorkes.

Teknik analisis data yang di gunakan dalam penelitian ini adalah: pengujian persyaratan analisis dengan uji normalitas menggunakan uji homogenitas dan menggunakan uji varians kedua kelompok sampel yang bertujuan untuk mengetahui apakah data di gunakan berasal dari populasi yang berdistribusi normal.

\section{HASIL DAN PEMBAHASAN}

Deskriptif data hasil penelitian tentang motivasi dan status gizi terhadap hasil belajar pada sampel, secara keseluruhan data yang dikumpulkan dapat dianalisis secara keseluruhan. Berarti seluruh sampel yang terdiri siswa putera secara baik dapat mengikuti tes dengan 
baik. Data penelitian tersebut adalah sebagai berikut :

\section{Motivasi}

Dari 20 orang siswa yang dijadikan sampel dalam penelitian ini, ternyata data tentang motivasi dapat memenuhi syarat untuk dianalisis. Pengukuran motivasi belajar dilakukan dengan penyebaran angket terhadap 20 orang sampel, didapat skor tertinggi 125 , skor terendah 95 , ratarata (mean) 108,1 dan simpangan baku (standar deviasi) 7,711. Setelah data terkumpul kemudian, data disusun dalam sebuah tabel distribusi dengan kelas interval.

\section{Tabel 4. Distribusi Frekuensi}

\section{Hasil Motivasi}

\begin{tabular}{|c|c|c|c|}
\hline No & $\begin{array}{c}\text { Kelas } \\
\text { interval }\end{array}$ & $\begin{array}{c}\text { Frekuensi } \\
\text { absolute } \\
\text { (Fa) }\end{array}$ & $\begin{array}{c}\text { Frekuensi } \\
\text { relative (Fr) }\end{array}$ \\
\hline 1 & $96-101$ & 3 & 15 \\
\hline 2 & $102-107$ & 6 & 30 \\
\hline 3 & $108-113$ & 6 & 30 \\
\hline 4 & $114-119$ & 4 & 20 \\
\hline 5 & $120-125$ & 1 & 5 \\
\hline & Jumlah & 20 & $100 \%$ \\
\hline
\end{tabular}

Berdasarkan tabel di atas dari 20 siswa yang terdapat hasil motivasi dengan rentangan 96-101 sebanyak 3 oran $(15 \%)$, kemudian hasil motivasi ya berada pada rentangan 102-107 sebany 6 orang $(30 \%)$, sedangkan 6 orang $(30$, , terdapat hasil motivasi belajar siswa dengan rentangan 108-113, selanjutnya ada 4 orang siswa (20\%) berada pada hasil motivasi belajar siswa dengan rentangan 114-119, dan terakhir terdapat juga hasil motivasi belajar siswa dengan rentangan 120-125 yaitu sebanyak 1 orang (5\%). Untuk lebih jelasnya dapat dilihat pada grafik di bawah ini

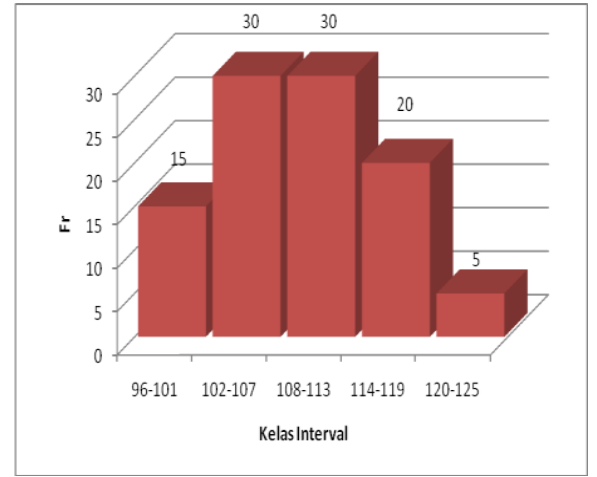

Grafik 2. Distribusi motivasi belajar

\section{Status gizi}

Pengukuran status gizi dilakukan dengan NHCS yaitu mengukur berat badan siswa terhadap 20 orang sampel, didapat skor tertinggi 104,3, skor terendah 67,6, rata-rata (mean) 85,02 dan simpangan baku (standar deviasi) 9,44. Setelah data terkumpul kemudian, data disusun dalam sebuah tabel distribusi dengan kelas interval.

Tabel 5. Distribusi Frekuensi Tes Status gizi

\begin{tabular}{|c|c|c|c|}
\hline No & $\begin{array}{c}\text { Kelas } \\
\text { interval }\end{array}$ & $\begin{array}{c}\text { Frekuensi } \\
\text { absolute } \\
\text { (Fa) }\end{array}$ & $\begin{array}{c}\text { Frekuensi } \\
\text { relative (Fr) }\end{array}$ \\
\hline 1 & $\begin{array}{c}67.60- \\
74.94\end{array}$ & 1 & 5 \\
\hline 2 & $\begin{array}{c}74.95- \\
82.29\end{array}$ & 8 & 40 \\
\hline 3 & $\begin{array}{c}82.30- \\
89.64\end{array}$ & 4 & 20 \\
\hline 4 & $\begin{array}{c}89.65- \\
96.99\end{array}$ & 5 & 25 \\
\hline 5 & $97.00-$ & 2 & 10 \\
104.34 & & $100 \%$ \\
\hline & Jumlah & 20 & \\
\hline
\end{tabular}

Berdasarkan tabel di atas dari 20 orang siswa putera, yang terdapat pada rentangan nilai dari hasil status gizi 67,6074,94 sebanyak 1 orang (5\%). Sebanyak 8 orang $(40 \%)$ terdapat hasil status gizi siswa dengan rentangan nilai 74,95-82,29, sedangkan sebanyak 4 orang (20\%) terdapat hasil status gizi siswa dengan rentangan nilai 82,30-89,64. Pada hasil status gizi siswa yang berada pada rentangan nilai 89,65-96,99 sebanyak 5 orang (25\%), dan yang terakhir ada 2 orang $(10 \%)$ berada pada hasil status gizi 
dengan rentangan 97,00-104,34.. Untuk lebih jelasnya dapat dilihat pada grafik di bawah ini.

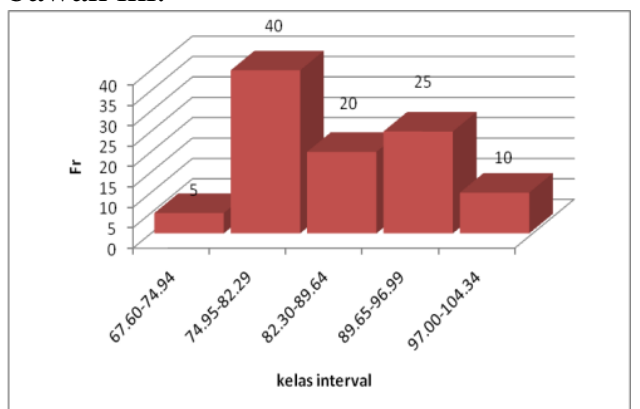

\section{Grafik 3. Distribusi Status gizi Siswa}

\section{Putera}

\section{Hasil Belajar}

Hasil belajar siswa diperoleh dari hasil nilai praktek terhadap 20 orang sampel, didapat skor tertinggi 85, skor terendah 70, rata-rata (mean) 77 dan simpangan baku (standar deviasi) 5,23. Setelah data terkumpul kemudian, data disusun dalam sebuah tabel distribusi dengan kelas interval.

Tabel 6. Distribusi Frekuensi hasil belajar

\begin{tabular}{|c|c|c|c|}
\hline No & $\begin{array}{c}\text { Kelas } \\
\text { interval }\end{array}$ & $\begin{array}{c}\text { Frekuensi } \\
\text { absolute } \\
\text { (Fa) }\end{array}$ & $\begin{array}{c}\text { Frekuensi } \\
\text { relative (Fr) }\end{array}$ \\
\hline 1 & $70-73$ & 4 & 20 \\
\hline 2 & $74-77$ & 8 & 40 \\
\hline 3 & $78-81$ & 4 & 20 \\
\hline 4 & $82-86$ & 4 & 20 \\
\hline & Jumlah & 20 & $100 \%$ \\
\hline
\end{tabular}

Berdasarkan tabel di atas dari 20 orang siswa putera, yang terdapat pada rentangan nilai dari hasil belajar siswa 70 73 sebanyak 4 orang (20\%). Sebanyak 8 orang $(40 \%)$ terdapat hasil belajar siswa dengan rentangan nilai 74-77, sedangkan sebanyak 4 orang (20\%) terdapat hasil belajar siswa dengan rentangan nilai 7881 , dan yang terakhir ada 4 orang (20\%) berada pada hasil belajar dengan rentangan 82-86. Untuk lebih jelasnya dapat dilihat pada grafik di bawah ini.

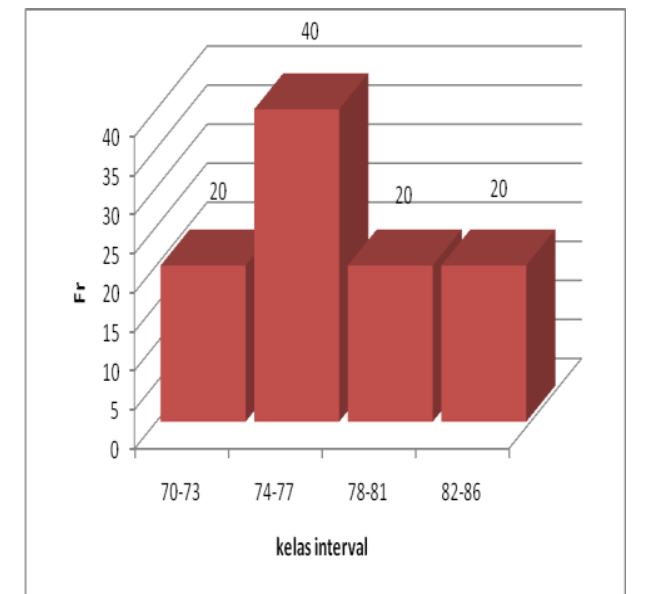

Grafik 4. Distribusi Hasil Belajar Siswa Putera

\section{B. Uji Persyaratan Analisis}

1. Uji Normalitas

Uji normalitas variabel dengan menggunakan uji Liliefors, dan hasil pengujian menunjukkan bahwa semua data dapat dikatakan penyebarannya normal dengan ditemukan Lo $<\mathrm{L}_{\text {tabel }}$, artinya data tersebut berditribusi normal. Hasil lengkap uji Liliefors dapat dilihat pada tabel berikut :

Tabel 7. Uji Normalitas Data

\begin{tabular}{|c|l|c|c|c|}
\hline NO & DATA & Lo & L tabel & Ket \\
\hline 1 & Motivasi & 0,1300 & $\mathbf{0 , 1 9 0}$ & Normal \\
\hline 2 & $\begin{array}{l}\text { Status } \\
\text { gizi }\end{array}$ & 0,1807 & $\mathbf{0 , 1 9 0}$ & Normal \\
\hline 3 & $\begin{array}{l}\text { Hasil } \\
\text { Belajar } \\
\text { Praktek }\end{array}$ & 0,0730 & $\mathbf{0 , 1 9 0}$ & Normal \\
\hline
\end{tabular}

2. Perhitungan Koefisien Korelasi Sederhana

Hasil pehitungan koefisien korelasi sederhana dapat dilihat sebagai berikut:

a. Hasil hitung koefisien korelasi nilai $\mathrm{X}_{1}$ terhadap $\mathrm{Y}$ adalah 0.497

b. Hasil hitung koefisien korelasi nilai $\mathrm{X}_{2}$ terhadap $\mathrm{Y}$ adalah 0.485

\section{Pengujian Hipotesis}




\section{Uji Hipotesis Satu}

Pengujian hipotesis pertama yaitu terdapat hubungan yang signifikan oleh motivasi belajar terhadap hasil belajar penjasorkes. Berdasarkan analisis dilakukan, maka didapat rata-rata motivasi siswa putera sebesar 108,1, dengan simpangan baku (standard deviasi) 7,71. Untuk skor rata-rata hasil belajar didapat 77 dengan simpangan baku (standar deviasi) 5,23. Dari keterangan di atas diperoleh analisis korelasi antara motivasi terhadap hasil belajar.

Tabel 8. Analisis korelasi antara motivasi terhadap hasil relajar $\left(\mathbf{X}_{2}-\mathbf{Y}\right)$

\begin{tabular}{|c|c|c|c|c|c|}
\hline $\mathrm{N}$ & $\mathrm{r}_{\text {hitung }}$ & $\begin{array}{c}\mathrm{r}_{\text {tabel }} \alpha \\
=0.05\end{array}$ & $\mathrm{t}_{\text {hitung }}$ & $\begin{array}{c}\mathrm{t}_{\text {tabel }} \alpha \\
=0.05\end{array}$ & $\begin{array}{c}\text { Kesimpula } \\
\mathrm{n}\end{array}$ \\
\hline 20 & $\begin{array}{c}0.49 \\
7\end{array}$ & 0.444 & $\begin{array}{c}2.97 \\
4\end{array}$ & 1.72 & Signifikan \\
\hline
\end{tabular}

Hasil perhitungan data tabel 10 menunjukkan bahwa koefisien kolerasi antara motivasi terhadap hasil belajar adalah positif, hal ini terlihat bahwa dari analisis statistik yang dilakukan dari data siswa diperoleh $\mathrm{r}_{\text {hitung }}$ sebesar 0.497 dan $\mathrm{r}$ table dalam taraf $\alpha=0.05$ sebesar 0.444 dengan demikian $r_{\text {hitung }}>r_{\text {tabel. }}$. Ini berarti terdapat hubungan yang berarti antara motivasi dengan hasil belajar penjasorkes.

\section{Uji Hipotesis dua}

Pengujian hipotesis kedua yaitu terdapat hubungan oleh status gizi terhadap hasil belajar penjasorkes. Berdasarkan analisis yang dilakukan terhadap siswa, maka didapat skor status gizi rata-rata hitung (mean) $=85,02$, standar deviasi $=9,44$, untuk skor rata-rata hasil belajar penjasorkes diperoleh ratarata hitung $($ mean $)=77$, standar deviasi $=$ 5,23. Dari keterangan di atas diperoleh analisis korelasi antara s Staus gizi dengan hasil belajar penjasorkesebagai berikut:

Tabel 9. Analisis Korelasi Antara status gizi Terhadap hasil belajar praktek $\left(\mathrm{X}_{2}-\mathrm{Y}\right)$

\begin{tabular}{|c|c|c|c|c|c|}
\hline $\mathrm{N}$ & $\mathrm{r}_{\text {hitung }}$ & $\begin{array}{c}\mathrm{r}_{\text {tabel }} \alpha \\
=0.05\end{array}$ & $\mathrm{t}_{\text {hitung }}$ & $\begin{array}{c}\mathrm{t}_{\text {tabel }} \alpha \\
=0.05\end{array}$ & $\begin{array}{c}\text { Kesimpula } \\
\mathrm{n}\end{array}$ \\
\hline 20 & $\begin{array}{c}0.48 \\
5\end{array}$ & 0.444 & $\begin{array}{c}2.35 \\
3\end{array}$ & 1.72 & Signifikan \\
\hline
\end{tabular}

Hasil perhitungan tada tabel 9 menunjukkan bahwa koefisien kolerasi anatara status gizi terhadap kemampuan hasil belajar penjasorkes adalah positif, hal ini terlihat bahwa dari analisis statistik yang dilakukan dari data siswa putera diperoleh $\mathrm{r}$ hitung sebesar 0.485 dan $\mathrm{r}$ table dalam taraf $\alpha=0.05$ sebesar 0.444 dengan demikian $r_{\text {hitung }}>r_{\text {tabel. }}$. Ini berarti terdapat hubungan yang berarti antara status gizi dengan hasil belajar penjasorkes.

\section{Pengujian Hipotesis tiga}

Pengujian hipotesis tiga yaitu terdapat hubungan antara status gizi dan motivasi secara bersama-sama terhadap hasil belajar. Berdasarkan analisis yang dilakukan Jika $f_{\text {hitung }}>f_{\text {tabel }}$ maka terdapat hubungan dan sebaliknya tidak terdapat hubungan jika $\mathrm{f}_{\text {hitung }}<\mathrm{f}_{\text {tabel }}$. Dari hasil perhitungan diperoleh koefisien korelasi ganda (uji $\mathrm{F}$ ) data siswa didapat $\mathrm{F}$ hitung $=$ 5,014 sedangkan $F_{\text {tabel }} 3.52$ yang diperoleh dengan $\mathrm{N}-\mathrm{K}-1 / 20-2$ jadi $\mathrm{F}_{\text {hitung }}>\mathrm{F}_{\text {tabel, }}$, selanjutnya hasil perhitungan $\mathrm{R}$ (korelasi berganda) siswa kelas putera secara bersama-sama hubungan motivasi belajar $\left(\mathrm{X}_{\mathrm{I}}\right)$ dan status gizi $\left(\mathrm{X}_{2}\right)$ dengan hasil belajar penjasorkes $(\mathrm{Y})$ sebesar 0.609 .

\section{Pembahasan}

Menurut Prayitno (1989:8) motivasi belajar tidak saja merupakan suatu energi yang menggerak siswa untuk belajar, tetapi juga sebagai usaha yang mengarahkan aktivitas siswa kepada tujuan belajar.

Dengan memperhatikan pendapat yang berkenaan dengan definisi motivasi, maka dapat disimpulkan bahwa motivasi merupakan dorongan dan rangsangan yang terjadi di dalam diri individu yang diwujudkan kepada tingkah laku untuk 
memenuhi kebutuhan yang diinginkan. Dengan terwujudnya motivasi ke dalam bentuk tingkah laku, maka dapat diketahui dan diramalkan apa yang menjadi tujuan individu.

Suatu kenyataan yang perlu disadari oleh guru-guru bahwa siswa yang dihadapi dikelas tidak sama dengan yang lainnya. Siswa mempunyai perbedaan dalam banyak hal seperti berbeda kemampuan berfikir baik bakat dan minat, siswa yang lambat dalam belajar ssering mengalami kesulitan, sebab setiap akhir kegiatan belajar siswa belum mampu untuk menguasai seluruh materi, akan tetapi guru telah melanjutkan pada materi lainnya. Akibatnya timbul pada siswa tersebut lebih sering tidak ada perhatian dan minat terhaadap pelajaran, sehingga siswa tersebut sering membolos, datang terlambat, tidak mengerjakan PR, lambat dalam pelaksanaan tugas yang diberikan oleh guru.

Dari uraian di atas dapat diambil kesimpulam bahwa motivasi belajar adalah dorongan atau kekuatan dalam diri siswa yang menimbulkan kegiatan serta arah belajar untuk mencapai tujuan yang diinginkan. Ini terlihat dari hasil perhitungan korelasi antara motivasi belajar dengan hasil belajar penjasorkes siswa diperoleh $r_{\text {hitung }}$ 0,497, sedangkan $\mathrm{r}_{\text {tabel }}$ pada taraf signifikan $=0.05$ yaitu0,444. Berarti dalam hal ini terdapat hubungan antara motivasi belajar dengan hasil belajar penjasorkes.

Dari hasil analisis di atas dapat diambil kesimpulan bahwa terdapat hubungan antara motivasi belajar dengan hasil belajar penjasorkes siswa SD Negeri 40 Sungai Lareh Kota Padang. Tingkat hasil belajar penjasorkes yang dimiliki siswa tentu akan lebih baik apabila tidak mengabaikan faktor-faktor yang dapat mempengaruhi perkembangan hasil belajar penjasorkes tersebut.

Khumadi, (1994:5) menjelaskan bahwa: zat gizi adalah zat-zat yang di peroleh dari bahan-bahan makanan yang kita makan. Tiap-tiap makanan yang kita makan mempunyai nilai yang sangat penting bagi tubuh. Sedangkan menurut Sunita (2001:3) zat gizi merupakan "ikatan-ikatan kimia yang di perlukan tubuh untuk melakukan fungsinya, yaitu: menghasilkan energi, membangun dan memelihara jaringan serta mengatur proses kehidupan".

Berdasarkan kutipan di atas, dapat di simpulkan bahwa status gizi dapat di artikan sebagai ikatan-ikatan kimia yang di perlukan tubuh atau zat makanan yang di kosumsi seseorang merupakan indikator dari status gizi mereka. Energi yang di perlukan untuk kinerja fisik di peroleh dari metabolisme bahan makanan yang di kosumsi sehari-hari, sehingga makanan atau zat gizi merupakan salah satu penentu kuslitas kinerja fisik dan pertumbuhan serta perkembangan fisik seseorang

Dari uraian yang sudah di sampaikan, didapat hasil perhitungan korelasi antara status gizi dengan hasil belajar penjasorkes siswa diperoleh $r_{\text {hitung }}$ 0,485 sedangkan $t_{\text {tabel }}$ pada taraf signifikan $\square=0.05$ yaitu 0,444 . Berarti dalam hal ini terdapat hubungan antara status gizi dengan hasil belajar.

Dari hasil analisis yang sudah di dapat, maka jelas bahwa terdapat hubungan antara status gizi terhadap hasil belajar siswa. Hasil belajar yang dimiliki siswa tentu akan lebih baik apabila tidak mengabaikan faktor-faktor yang dapat mempengaruhi hasil belajar tersebut.

Soetjiningsih mengemukakan bahwa "Gizi yang tidak seimbang dapat mengganggu pertumbuhan seseorang sehingga terlihat anak kurang bersemangat, kurang bergairah, pucat, kurang darah, daya ingat menurun, lebih mudah di serang bibit penyakit dan mengantuk pada jam pelajaran. Sedangkan gizi lebih adalah gizi yang tidak seimbang yang dapat menyebabkan kelebihan berat badan atau obesitas".

Hasil yang diperoleh sesuai dengan norma status gizi, menggmbarkan bahwa, yang memiliki status gizi yang baik sebanyak 7 orang atau indeks mediannya 
sebesar $90 \%$. Kemudian pada gizi sedang 6 orang dan gizi kurang yaitu terdapat 6 orang dan sisanya sebanyak 1 orang yang terdapat gizi buruk.

Jadi dapat di tarik kesimpulan bahwa rata-rata siswa SD Negeri 40 Sungai Lareh Kota Padang berada pada gizi sedang. Dari pendapat di ats jelas bahwa siswa yang kurang gizi dapat mengakibatkan siswa kurang bersemangat dan kurang bergairah. Akibat dari kurang bersemangat maupun kurang bergairah, maka akan menimbulkan hasil belajar kurang baik.

Dalam proses pembelajaran apapun bentuknya, motivasi belajar siswa mutlak diperlukan. Hal ini dikarenakan motivasi belajar bagi siswa adalah pendorong, penentu dan mengarahkan siswa untuk dapat melaksanakan kegiatan belajar dengan sungguh-sungguh guna mencapai hasil belajar yang optimal sesuai dengan tujuan yang diharapkan. Begitu juga halnya dengan motivasi belajar dalam Penjas Orkes, tanpa adanya motivasi siswa yang tinggi maka hasil belajar sulit untuk dicapai sesuai dengan yang diharapkan. Oleh sebab itu, motivasi belajar siswa penting artinya dalam pembelajaran pendidikan jasmani.

Penilaian status gizi pada dasarnya merupakan proses pemeriksaan keadaan gizi seseorang dengan cara mengumpulkan data penting, baik yang bersifat objektif maupun subjektif.Status gizi adalah keadaan tubuh sebagai akibat kosumsi,penyerapan, penggunaan pangan di dalam tubuh, dan mengkosumsi zat-zat makanan dalam waktu yang lama. Parameter penting dalam menentukan status gizi ini adalah bobot atau berat badan yang di miliki seseorang.

Untuk mengetahui hubungan dari dua variabel atau lebih digunakan rumus korelasi ganda. Kriteria pengujian signifikan dengan uji $\mathrm{F}$ (sudjana, 2002: 385). Jika $f_{\text {hitung }}>\mathrm{f}$ tabel maka terdapat hubungan dan sebaliknya tidak terdapat hubungan jika $\mathrm{f}_{\text {hitung }}<\mathrm{f}_{\text {tabel. }}$. Dari hasil perhitungan diperoleh koefisien korelasi ganda (uji $\mathrm{F}$ ) siswa didapat $\mathrm{F}_{\text {hitung }}=5,014$ sedangkan $\mathrm{F}_{\text {tabel }}$ diperoleh dengan $\mathrm{N}-\mathrm{K}$ $1 / 20-2-1=18$ sebesar 3.52 jadi $F_{\text {hitung }}>$ $\mathrm{F}_{\text {tabel, }}$ selanjutnya hasil perhitungan $\mathrm{R}$ (korelasi berganda) secara bersama-sama tingkat hubungan motivasi belajar $\left(\mathrm{X}_{\mathrm{I}}\right)$ dan status gizi $\left(\mathrm{X}_{2}\right)$ dengan hasil belajar penjasorkes (Y) sebesar 0.609.

Hasil belajar merupakan hasil akhir yang di peroleh dari hasil pembelajaran yang di lakukan. Hasil belajar yang di peroleh masing-masing siswa tidaklah sama, selain itu hasil belajar masingmasing siswa sangatlah di pengaruhi oleh banyak faktor antara lain kesegaran jasmani,gizi yang di kosumsi sehari-hari, lingkungan sekolah, kesehatan lingkungan, keadaan ekonomi dan lain-lain.

Dari hasil yang telah dikemukakan di atas dapat buktikan bahwa faktor motivasi belajar siswa dan status gizi merupakan faktor penentu hasil belajar penjasorkes. Jadi unsur status gizi dan motivasi belajar dapat memberikan hubungan kepada hasil belajar penjasorkes, sehingga siswa tersebut mampu meraih hasil yang maksimal.

\section{KESIMPULAN}

Berdasarkan kesimpulan di atas, maka peneliti dapat memberikan saransaran sebagai berikut:

1. Sekolah dapat memperhatikan motivasi belajar status gizi siswa agar siswa mendapatkan hasil belajar yang baik

2. Siswa harus memiliki motivasi yang tinggi, agar dapat memperoleh hasil belajar yang baik.

3. Siswa agar memperhatikan status gizi sehingga dapat menghasilkan hasil belajar penjasorkes yang baik pula.

4. Siswa agar dapat memperhatikan faktor-faktor yang mempengaruhi hasil belajar

5. Bagi para peneliti disarankan untuk dapat mengkaji faktor-faktor lain yang berhubungan dengan hasil belajar. 


\section{DAFTAR PUSTAKA}

Ahmadi, Abu dan Widodo Supriyono, (19991). Ilmu Pendidikan Umum, Jakarta : Rineka Cipta

Arikunto, Suharsimi. 1992. Prosedur Penelitian. Jakarta: Rineka Cipta.

Depertemen Kesehatan Republik Indonesia. 1994 : Gizi Olahraga Sehat. Bugar dan Berprestasi. Jakarta. Direktorat Bina Gizi Masyarakat.

Depkes RI. 1999. Direktorat Bina Gizi Masyarakat. Jakarta. Depkes RI.

Khumadi, 1994. Bahan Pangan dan Olahan, Jakarta. Balai Pustaka.

Kuntaraf, dkk. 1999. Makanan Sehat Bandung: Indonesia Publising House

Peraturan Menteri No. 22 Tahun 2006 Tentang Standar Mutu Dan Isi, Jakarta, 2006

Purwanto, Ngalim. 1990. Psikologi Pengajaran. Bandung: Bumi Aksara.

Riduwan. 2005. Skala Pengukuran Variabel-variabel penelitian. Bandung : Alfa Beta.

Riyadi, (1995) Tinggi Badan dan Antropmetri. Jakarta gramedia.

Setyobroto, Sudibyo. 1984. Psikologi Olahraga. Jakarta : Percetakan Universitas Negeri Jakarta.

Sukmadinata. (2003). Landasan psikologi proses pendidikan.Bandung : $\mathrm{PT}$. Remaja Rosda Karya
Sudjana. (1991). Penilaian Belajar Mengajar,Bandung : PT. Remaja Rosda Karya.

Soemanto. 1990. Psikologi Pendidikan, Jakarta: Rineka Cipta.

Suryabrata, Sumadi. 1984. Psikologi Pendidikan. Yogyakarta: UPT MKK UNNES Semarang Press

Soetjiningsih, 1998. Pedoman Gizi Seimbang. Jakarta: PT. Grafindo

Syafrizar,dkk. 2009. Gizi olahraga, Fakultas Ilmu Keolagragaan Uniersitas Negeri Padang, Cetakan pertama Maret, Wineka Pertama.

Undang-undang Republik Indonesia No.20 tahun 2003. Tentang sistem pendidikan Nasional. Jakarta:Depdikbud.

Winkell WS. 1984. Psikologi Pendidikan dan Evaluasi Belajar. Jakarta: PT. Gramedia

Wirakusuma. 1997. Ilmu Gizi. Jakarta Bratara Karya Aksara.

Witherington. 1986. Teknik-teknik Belajar dan Mengajar. Bandung : Jemmers 